Jurnal Konstruksi Hukum | ISSN: 2746-5055

Vol. 2, No. 1, Januari 2021 Hal. 57-61 | Tersedia online di https://www.ejournal.warmadewa.ac.id/index.php/jukonhum

DOI: https://10.22225/jkh.2.1.2968.57-61

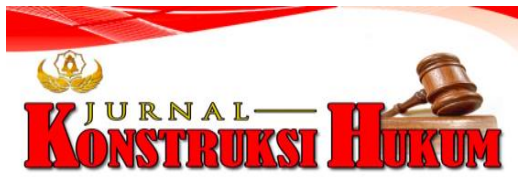

\title{
AKIBAT HUKUM PEKERJA ANAK MENURUT UNDANG-UNDANG NOMOR 13 TAHUN 2003
}

\author{
I Gusti Ngurah Winda Aditya Putra, I Nyoman Putu Budiartha, Luh Putu Suryani \\ Fakultas Hukum Universitas Warmadewa, Denpasar-Bali, Indonesia
}

\begin{abstract}
Abstrak
Anak yang dilahirkan ke dunia ini secara otomatis akan menjadi penerus bangsa dan menjadi kebanggaan bagi orang tuanya. Namun, perbedaan ekonomi setiap anak dari orang tuanya menyebabnya banyak diantara mereka sudah bekerja sejak dini bahkan sampai memutuskan untuk berhenti menempuh pendidikan demi mencukupi kebutuhannya. Penelitian ini bertujuan untuk menganalisis akibat hukum memperkerjakan ana menurut perspektif perundung-undangan. Penelitian ini menggunakan metode penelitian hukum normatif adalah hukum kepustakaan yang mengacu pada norma hukum yang terdapat dalam peraturan Perundang-undangan. Hasil penelitian menunjukan bahwa pekerjaan apapun yang dilakukan oleh seorang anak tentu tidak lepas dari pengawasan orang tua dan telah mendapatkan ijin dari orang tua. Pendidikan yang baik membuat penerus bangsa membuat luasnya wawasan yang dimiliki yang bisa dimanfaatkan nanti saat melakukan suatu pekerjaan. Mempekerjakan seorang anak dibawah umur merupakan suatu pelanggran yang dapat diberi sanksi pidana kebahagiaan yang direnggut saat usia anak-anak sudah melakukan pekerjaan membuat anak menjadi keterbelakangan mental atau pemikiran dan usianya nanti tidak sejalan lagi.
\end{abstract}

Kata Kunci: Akibat Hukum Pekerja Anak, Hak anak, perlindungan anak

\begin{abstract}
Children who are born into this world will automatically become the successor of the nation and become the pride of their parents. However, the economic difference between each child and their parents causes many of them to work from an early age and even decide to stop taking education to meet their needs. This study aims to analyze the legal consequences of employing children from a legislative perspective. This study uses a normative legal research method, which is literature law which refers to the legal norms contained in statutory regulations. The results of the study show that any work done by a child cannot be separated from the supervision of the parents and has received permission from the parents. A good education makes the nation's successors broaden the knowledge they have that can be used later when doing a job. Employing a minor child is an offender who can be given a criminal sanction of happiness that is snatched when the child is already doing work, making the child become mentally retarded or thought and his age is no longer compatible.
\end{abstract}

Keywords: Legal consequences of child labor, children's rights, child protection

\section{PENDAHULUAN}

Anak yang dilahirkan ke dunia ini secara otomatis akan menjadi penerus bangsa dan menjadi kebanggaan bagi orang tuanya. Namun, perbedaan ekonomi setiap anak dari orang tuanya menyebabnya banyak diantara mereka sudah bekerja sejak dini bahkan sampai memutuskan untuk berhenti menempuh pendidikan demi mencukupi kebutuhannya. Apalagi bila kondisi kedua orang tua tidak lagi produktif untuk mencari nafkah sudah seharusnya seorang anak menjadi tulang punggung keluarga menggantikan orang tuanya yang sudah tidak mampu lagi menafkahi keluarga kondisi ini menyebabkan banyak diantara anak yang seharusnya di usia mereka berdanda gurau menjadi fokus kepada ekonomi keluarga. Demi menjadi penerus orang tuanya seharusnya seorang anak mendapatkan fasilitas yang menunjang aktivitasnya demi menjadi seorang yang dibanggakan suatu hari nanti. Namun didalam keluarga yang keadaan ekonomi kurang seorang anak dipaksa bekerja sedari dini demi mencukupi hidupnya dan keluarga (Bagong, 1996). Seakan tidak memperdulikan kesehatannya banyak anak yang bekerja dalam kondisi yang tidak layak seperti yang sering mereka lakukan diperbatasan jalan meminta tanpa menggunakan topi dan alas kaki. Seperti tontonan yang sudah menjadi hal yang dibiasa ketika pengendara motor atau mobil berhenti di setiap lampu merah. Setiap mereka menadahkan tangan ke arah kendaraan itu artinya mereka sedang lapar atau meminta uluran tangan dari kendaraan untuk memberikan sedikit rejekinya demi mereka bisa mengganjal perut mereka. 
Di setiap ibu kota di Indonesia pasti menemukan banyak anak yang meminta - minta dijalanan betapa banyaknya anak yang sejak kecil mencari nafkah untuk keluarganya dan bahkan anak balita pun ada yang di gendong orang tuanya demi mendapatkan rupiah dari para pengendara Tingkat kemiskinan yang tiap tahun semakin meningkat tidak bisa dipungkiri menjadi sebab utama banyaknya anak - anak yang menjadi tulang punggung keluarga. Nilai budaya yang dimiliki oleh anak akan dikembangkan dalam kehidupan bermasyarakat. Seharusnya para orang tua menjadi contoh bagi buah hati mereka bukannya memanfaatkan mereka demi mendapatkan uang disamping itu para orang tua melihat terlebih dahulu ekonomi sendiri sebelum membuat anak agar ketika dia lahir mendapatkan kelayakan kehidupan.

Hidup yang difungsikan sedari kecil hanya mencari uang dan uang akan menyebabkan pola pikir anak menjadi keterbelakang membuat mereka semakin dewasa semakin kurang pengetahuan. Kondisi ini menyebabkan prihatin bagi kita dengan kondisi ekonomi yang berkecukupan dan bisa menjadi perbuatan kriminal dikemudian hari karena mereka frustasi pada keadaan sendiri.

Badan Pemberdayaan Perempuan dan Perlindungan Anak (BPPPA) mendata anak - anak yang hidupnya terlantar sudah ada yang banyak sekali memutuskan berhenti sekolah demi bekerja di jalan sebagai peminta - minta bahkan ada yang sampai belasan tahun sudah putus sekolah dan melakukan kegiatan minta - minta dari pagi hingga malam hari tanpa memikirkan kesehatan mereka. Di sisi lainnya ada beberapa sekolah yang bahkan memberhentikan muridnya karena sifatnya yang berbeda dari anak pada umumnya sebagai tempat menuntut ilmu sekolah sudah seharusnya memberikan pembelajaran diluar lingkungan orang tua mereka bukannya menolak sebagai sarana prasarana dalam mendidik seorang murid. Undang-Undang Perlindungan Anak dan Badan Pemberdayaan Perempuan dan Perlindungan Anak (BPPPA) bersama pemerintah memberikan jaminan pendidikan kepada setiap anak yang mengalami putus sekolah namun banyak diantara mereka karena sudah nyaman dengan zonanya sekarang memilih untuk tidak melanjutkan sekolahnya kondisi yang sangat disayangan padahal pemerintah sudah menanggung pendidikannya tetapi anak itu menolaknya. Disini orang tua yang sangat memberikan peran nyata supaya seorang anak mau kembali bersekolah dengan cara bicara dari hati ke hati buat seorang anak menjadi nyaman kembali bersekolah. Salah satu alasan kenapa anak tidak ingin bersekolah lagi disamping sudah bisa menghasilkan uang adalah rasa malu karena perbedaan usia dia saat ini dengan temannya yang melanjutkan pendidikan. Sebuah fenomena yang unik yang sering terjadi di Indonesia dikarenakan perekonomian yang tidak stabil dan naik turun menyebabkan banyaknya tingkat pengangguran dari orang yang merembes pada keturunannya. Penelitian ini berbeda dengan penelitian-penelitian lainnya yang pernah dilakukan, salah satunya tentang perlindungan kerja anak menunjukkan bahwa Pekerja anak telah mendapatkan perlindungan yang cukup dari peraturan perundang-undangan Indonesia (Prajnaparamita, 2018), kedua mengenai permasalahan hukum tentang tenaga kerja anak di Indonesia menunjukkan bahwa pengusaha yang mempekerjakan anak harus memperhatikan ketentuan yang ada pada UU No.13 tahun 2003 tentang Ketenagakerjaan, apabila melanggar UU tersebut maka dikenakan sanksi pidana dan sanksi administratif (Purnamawanti \& Zulkarnaen, 2004), terakhir tentang perlindungan hukum bagi pekerja anak berdasarkan undang-undang nomor 13 tahun 2003 tentang ketenagakerjaan (Aditya, Sarjana, \& Udiana, 2019).

\section{METODE PENELITIAN}

Pencarian informasi secara normatif berpatokan pada peraturan pemerintah yang berfokus pada anak sebagai objeknya dan analisis dalam Informasi yang didapat secara konseptual berkaitan dengan kajian ini (Marzuki, 2011). Penelitian ini menggunakan metode normatif dan kualitatif dimana dalam pengerjaannya penulis menelaah isu hukum dengan didasari peraturan-peraturan hukum Perbankan di Indonesia. Penelitian hukum normatif adalah hukum kepustakaan yang mengacu pada norma hukum yang terdapat dalam peraturan Perundang-undangan. Pendekatan perundangan - undangan adalah melakukan suatu penelitian dengan berpatokan pada undang - undang sebagai dasar penelitian ini (Soekanto \& Mamudji, 2018). Pendekatan kasus dilakukan guna melihat mencatat dan memahami permasalahan yang diangkat dalam penelitian ini dengan tidak keluar dari zona hukum positif.

\section{HASIL DAN PEMBAHASAN}

Indonesia merupakan negara dengan banyak proyek infrastruktur dengan nilai fantastis peran tenaga kerja sangat penting dalam pembangunan bangunan tersebut. Sebagai perusahaan yang mengharapkan 
hasil maksimal dalam pembangunannya seyogyanya tidak melupakan kesejahteraan tenaga kerja seperti upah yang telah disepakati bersama sampai tunjangan kesehatan. Peran pemerintah sebagai yang memberikan perlindungan bagi tenaga kerja di Indonesia sebijak mungkin dalam memberikan pelayanan kepada tenaga kerja (Endrawati, 2012). Keselamatan kerja dan kesehatan merupakan hal penting yang harus didapatkan oleh tenaga kerja agar mereka dalam bekerja tidak merasa terbebani dengan demikian pembangunan infrastruktur sesuai dengan apa yang diminta oleh pemilik perusahaan atau pemerintah. Menurut, Soepomo (2009), ada 3 bentuk perlindungan tenaga kerja di Indonesia, yaitu:

1. Perlindungan ekonomis disebut juga jaminan sosial merupakan usaha pemerintah dalam memberikan segala kebutuhan bagi pekerja selama melakukan pekerjaannya memberikan kompensasi bagi pekerja yang tidak bisa bekerja karena suatu hal.

2. Perlindungan sosial merupakan suatu upaya kemasyarakatan dimana tenaga kerja diharapkan tidak hanya pada titik itu saja sebagai seorang pekerja sudah seharunya selalu mengembangan diri dan jangan hanya memperhitungkan pekerjaannya. Aktivitas ini tidak lain halnya dengan kesehatan kerja.

3. Perlindungan teknis sama halnya dengan keselamatan kerja kehidupan para tenaga kerja dijamin oleh pemerintah agar selalu nyaman dalam melakukan pekerjaannya dan diberikan tanggungan apa bila terjadi kecelakaan dalam pekerjaannya.

Dengan demikian dalam melaksanakn pekerjaannya tenaga kerja anak harus mendapatkan perlindungan untuk menghindari tindakan pengusaha yang semena- mena terhadap tenaga kerja tersebut guna mendapatkan tenaga kerja yang murah. Dengan adanya kenyataan yang demikian maka diperlukan adanya perlindungan sosial yang berupa keselamatan dan kesehatan kerja.

Faktor penyebab pekerja anak melakukan pekerjaan disebabkan karena faktor ekonomi yang bersangkutan untuk mengambil pekerjaan tersebut karena menganggap bahwa pekerjaan di Perusahaan itu tidak menggangu jam sekolah. Sehingga bagi mereka tidak ada masalah jika tetap bekerja dalam keadaan sekolah dan merasa bahwa aktivitas kerjanya pun tidak terganggu. Bagi pekerja anak yang masih dibawah umur pihak perusahaan tidak memberikan perlakuan khusus sebagai pekerja tersebut dan tidak ada kesempatan yang sepatutnya untuk belajar ketika bekerja Hal ini didukung pula dengan kenyataan bahwa pada umumnya sebelum berangkat kerja dalam hal ini bekerja sebagai Cleaning Service dan waktunya setelah pulang sekolah yang sudah ada ijin dari orangtuanya. Hal ini juga merupakan hambatan bagi perusahaan untuk menerapkan peraturan yang kaitannya tentang perlindungan bagi anak sebagai pekerja.

Kehadiran dan etos kerja dari pekerja anak inilah menjadikan pasal 68 UU RI Nomor 13 Tahun 2003 tidak dapat diterapkan sepenuhnya dalam suatu perusahaan dan tetap memerlukan kebijakan tersendiri dari pihak pengusaha dengan kesepakatan yang telah dibuat bersama wakil pekerja anak. Dalam mengatasi kendala dan hambatan tersebut pihak perusahaan berupaya semaksimal mungkin untuk mewujudkan inti dari pasal tersebut sebagai tenaga kerja anak dengan memberikan kebijakan tertentu dengan diberlakukan setelah diadakan musyawarah antara pihak perusahaan dan wakil pekerja anak terlebih dahulu.

Pemberitahuan informasi mengenai tenaga kerja anak dapat dilakukan pemerintah melalui media cetak dan elektronik agar setiap perusahaan yang mempekerjakan anak di bawah umur tidak lagi melakukannya dan agar setiap perusahaan memahami tentang pentingnya kesehatan kerja terutama bagi anak sebagai prioritasnya. Pemerintah dalam usahanya melindungi setiap anak yang bekerja bukan pada usianya memberlakukan peraturan yang mengatur hak istimewa yang harus didapatkan setiap anak sebagai tenaga kerja. Sebagai anak yang menjadi tulang punggung keluarga agar mempertimbangkan lagi melanjutkan pendidikan yang telah ditanggung oleh pemerintah demi memajukan Indonesia.

Prestasi adalah bahasa hukum yang berarti kewajiban para pihak yang membuat suatu perjanjian (Subekti, 1984). Bagi pihak - pihak yang melakukan suatu perjanjian akan mendapatkan hak sesuai dengan kesepakatan perjanjian namun terlebih dahulu melakukan kewajibannya begitu pula kebalikannya semua pihak mendapatkan kewajiban yang sama dalam upayanya mendapat hak - hak yang diinginkannya.

Bahwa tujuan dari dibuatnya suatu perjanjian kerja pekerja anak adalah agar sebagai anak dapat memenuhi ekonominya dan dipihak yang lainnya mendapatkan suatu yang telah diperjanjikan baik pihak pekerja anak maupun pihak perusahaan dapat diketahui dan dipenuhi secara maksimal sehingga 
kalau terjadi pelanggaran hak dan kewajiban yang disebabkan oleh kelalaian ataupun kesengajaan dari seorang yang membuat perjanjian kepada seorang lain akan diselesaikan secara baik dan benar. Apalagi kalau dibuat secara tertulis dan dalam bentuk akta otentik sudah tentu hal ini akan sangat membantu dalam proses penyelesaian sengketa kalau mungkin terjadi.

Mengenai hak-hak dari pekerja anak secara umum dapat dibedakan dalam tiga fase (Soepomo, 1983) yaitu:

a. Hak pekerja anak sebelum bekerja

Setiap orang harus memiliki pendidikan dan skill sebagai salah satu persiapan terjun ke dunia kerja sehingga pengusaha dalam hal ini berkewajiban untuk memberikan pendidikan terutama pada saat calon pekerja magang di perusahaan tersebut. Selain itu pekerja juga harus jeli dalam melihat peluang pekerjaan yang diberikan oleh setiap perusahaan dan setiap calon pekerja juga berhak untuk mendapatkan kesempatan yang sama untuk mendapat pekerjaan.

b. Hak pekerja anak ketika bekerja

Hak-hak pekerja pada saat bekerja adalah mendapat upah yang layak merupakan hak bagi setiap tenaga kerja yang menyelesaikan kewajibannya untuk besarnya ditetapkan dan dibayarkan menurut ketentuan dalam suatu perjanjian kerja baik perjanjian kerja bersama (PKB) maupun peraturan perusahaan (PP). Bagi pekerja yang tidak bekerja dengan alasan cuti mogok yang sah pekerja sakit menjalankan kewajiban terhadap negara menjalankan ibadah melaksanakn tugas serikat melaksanakn tugas pendidikan dari perusahaan. Pekerja juga tetap berhak untuk mendapatkan gaji. Dan selain upah pekerja berhak juga untuk mendapatkan penghargaan lainnya seperti fasilitas yaitu sebuah kenikmatan dalam bentuk nyata untuk meningkatkan kesejahteraan pekerja (fasilitas rumah kendaraan seragam dan lain-lain). Pemberian bonus yaitu pembayaran yang diterima oleh pekerja dari hasil keuntungan perusahaan atau karena melebihi target produksi pemberian bonus yang menjadi hak setiap tenaga kerja menjelang liburan dan hari raya sesuai dengan kepercayaan masing - masing orang.

c. Hak pekerja anak setelah tidak bekerja

Meskipun hubungan kerja telah berakhir namun pekerja masih mendapatkan hak-hak mereka sesuai dengan ketentuan yang berlaku seperti harus ditaatinya dan dilaksanaknnya peraturan mengenai mekanisme pelaksanaan dari prosedur pemutusan hubungan kerja (PHK) tetap dibayarkannya upah selama pelaksanaan prosedur (selama proses) penetapan pemutusan hubungan kerja (PHK) dibayarkannya uang pesangon sesuai dengan ketentuan yang berlaku diberikannya santunan kematian oleh pihak asuransi dibayarkan hak pensiun bagi pekerja serta beberapa ketentuan lain sesuai dengan aturan yang diberlakukan diperusahaan tersebut.

Keadaan dimana seseorang berhak bekerja adalah usia delapan belas tahun dan seijin dari orang tuanya selama sebelum usia yang telah ditentukan seorang anak kehidupannya ditanggung oleh orang tuanya dan berhak mendapatkan pendidikan wawasan dan kebahagiannya dalam bergaul dilingkungannya. Eksploitasi adalah tindakan tidak terpuji yang dilakukan kedua orang tuanya karena memaksakan seorang anak melakukan pekerjaan yang seharusnya bukan usianya dia melakukan hal tersebut dengan paksaan dari orang tuanya maka perbuatan tersebut dilarang keras oleh pemerintah Perbuatan eksploitasi terhadap seorang anak membuat masa depan anak menjadi suram tidak mendapatkan pendidikan pergaulan dan pola pikir yang luas disamping itu semakin lama seorang anak di eksploitasi maka semakin tidak bebasnya dia dalam menjalani hidup. Mencari uang diusia dini dengan kondisi orang tua yang masih sehat dan produktif adalah hal sangat ditentang oleh banyak orang.

Kelahiran seorang anak di dunia ini sudah mendapatkan perlindungan hukum dan sudah diatur di peraturan yang mengikat sejak dia lahir jadi memperbudak seseorang demi keuntungan diri sendiri merupakan perbuatan yang melanggar undang - undang dan bisa dikenakan pidana. Jika hal ini dibiarkan berlarut - larut maka Negara Indonesia selamanya tidak akan maju karena disamping masyarakatnya banyak yang krisis ekonomi juga krisis moral dan akhlak.

Hubungan kerja antara atasan dengan tenaga kerja bisa terjaga dengan baik asalkan ada komunikasi dan tidak lupa memperhatikan kesejahteraan tenaga kerja yang bekerja kerena jika hal itu tidak dilaksanakn akan terjadi pelanggaran perjanjian kerja selain itu pemerintah tidak akan diam jika terjadi pelanggaran hak yang dilakukan pihak perusahaan kepada tenaga kerja (Sidabutar, 2007). 


\section{SIMPULAN DAN SARAN}

\section{Simpulan}

Pekerjaan apapun yang dilakukan oleh seorang anak tentu tidak lepas dari pengawasan orang tua dan telah mendapatkan ijin dari orang tua. Pendidikan yang baik membuat penerus bangsa membuat luasnya wawasan yang dimiliki yang bisa dimanfaatkan nanti saat melakukan suatu pekerjaan. Mempekerjakan seorang anak dibawah umur merupakan suatu pelanggran yang dapat diberi sanksi pidana kebahagiaan yang direnggut saat usia anak-anak sudah melakukan pekerjaan membuat anak menjadi keterbelakangan mental atau pemikiran dan usianya nanti tidak sejalan lagi.

\section{Saran}

Pemerintah sebagai penanggung jawab bagi penerus bangsanya agar selalu memperhatikan kesejahteraannya. Dimulai dari memperbaiki perekonomian negara yang nantinya akan membuat keadaan ekonomi setiap warganya membaik dan secara otomatis pihak perusahaan mempekerjaan anak dibawah umur lagi dan mereka mendapat kehidupan layaknya anak lainnya. Kemudian, orang tua sebagai panutan bagi seorang anak seyogyanya memberikan kehidupan layak bagi buah hatinya masal pendidikan yang baik dan pergaulan yang tepat agar terciptanya anak yang mampu bersaing dimasa mendatang bukan memanfaatkan mereka guna memperoleh keuntungan pribadi.

\section{DAFTAR PUSTAKA}

Aditya, I. G. K. R., Sarjana, I. M., \& Udiana, I. M. (2019). Perlindungan Hukum Bagi Pekerja Anak Berdasarkan Undang-Undang Nomor 13 Tahun 2003 Tentang Ketenagakerjaan. Kertha Semaya, 7(2).

Bagong, S. (1996). Analisis Situasi Pekerja Anak dan Masalah Pendidikan Dasar. Surabaya: Universitas Airlangga Pres.

Endrawati, N. (2012). Perlindungan Hukum terhadap Pekerja Anak di Sektor Informal (Studi Kasus di Kota Kediri). Jurnal Dinamika Hukum, 12(2).

Marzuki, P. M. (2011). Penelitian Hukum. Jakarta: Kencana Prenida Media.

Prajnaparamita, K. (2018). Perlindungan Tenaga Kerja Anak. Adminitrative Law \& Governance Journal, 1(1).

Purnamawanti, P., \& Zulkarnaen, I. (2004). Permasalahan Hukum tentang Tenaga Kerja Anak di Indonesia. Lex Jurnalica, 2(1).

Sidabutar, E. S. (2007). Pedoman Penyelesaian PHK. Tanggerang: Banten Express.

Soekanto, S., \& Mamudji, S. (2018). Penelitian Hukum Normatif: Suatu Tinjauan Singkat (18th ed.). Jakarta: Rajawali Pers.

Soepomo, I. (1983). Hukum Perburuhan Bidang Hubungan Kerja. Jakarta: Djambatan.

Soepomo, I. (2009). Hukum Ketenagakerjaan Undang - Undang dan Peraturan-peraturan. Jakarta: Djambatan. Subekti, R. (1984). Hukum Perjanjian. Jakarta: PT. Intermasa. 